\title{
The Development of Organic Chemistry Teaching Materials on The Topic of Lipid Using Android STEM Based Approach
}

\author{
https://doi.org/10.3991/ijim.v16i03.28959 \\ Dewi Handayani ${ }^{1(凶)}$, Endang Widi Winarni ${ }^{1}$, Agus Sundaryono ${ }^{1}$, \\ M. Lutfi Firdaus ${ }^{1}$, Muzanip Alperi ${ }^{2}$ \\ ${ }^{1}$ University of Bengkulu, Bengkulu, Indonesia \\ ${ }^{2}$ Institution of Education Quality Assurance (LPMP), Bengkulu, Indonesia \\ a.handayani@unib.ac.id
}

\begin{abstract}
The purpose of this study was to develop teaching materials for Organic Chemistry 2 by using an android-based STEM approach, analyze the readability of teaching materials and determine student learning outcomes. This research belongs to the $R \& D$ type of the Borg and Gall model. This research was starting from the research and information gathering stage, planning, developing the initial product format, validation testing, initial product revision, field testing, product revision of field test results. The research subjects were undergraduate students of Chemistry Education who took organic chemistry courses 2 . The instruments in this research were a material expert validation questionnaire, media expert validation and evaluation test sheets. The results showed that the teaching materials developed were considered feasible by the material expert validators with a percentage score of $93.33 \%$ and media experts $95.67 \%$. The data from the readability test of teaching materials averaged 92.38 with a very good category. Student learning outcomes pretest and posttest scores increased from 55.56 to 78.61 , the $\mathrm{N}$-gain value was 0.51875 in the medium category. Based on this, it can be concluded that organic chemistry 2 teaching materials using an android-based STEM approach are very feasible and can improve student learning outcomes.
\end{abstract}

Keywords — organic chemistry 2, STEM approach, android

\section{Introduction}

Seat of learning, especially the Faculty of Teacher Training and Education (FKIP) as educational institutions that produce teachers are responsible for preparing quality human resources. FKIP in this case the Chemistry Education Study Program must be able to prepare qualified graduates, able to compete globally and able to master the latest technological developments. Several attempts were made to create innovative human resources that capable to adapting in technological developments. Infrastructure is indispensable to support learning, especially in the industrial era 4.0 which requires information technology, big data analysis, product digitization, so it is expected to be 
able to produce graduates who are skilled in aspects of data literacy, technological literacy and human literacy. The latest innovation breakthroughs are able to increase industrial productivity and give rise to many companies based on digital technology [1]. The efforts made include developing teaching materials, learning tools, evaluation tools, in digital form either using certain applications, or through learning platforms such as e-learning management system Universty of Bengkulu (Unib), google classroom, edmodo, google forms, flash applications, professional pdf applications. The development of teaching materials that carried out will be tried on organic chemistry courses in digital form using an approach/model, so as to increase motivation, learning outcomes and student's digital literacy skills. It is necessary to apply several approaches, media and methods in learning in accordance with previous research which states that there is a correlation between variations in methods, media and learning resources on student competencies/learning outcomes [2].

Since the Covid-19 pandemic, student learning patterns have changed. At first it was full of face-to-face meetings in class. Currently the pattern of lectures is still using the Network (Online). This change in learning patterns makes lecturers have to be more creative in delivering teaching materials to students. The practice in the laboratory in 2020 is also changing. In 2020, students are still making individual reports based on experimental videos taken from YouTube or experimental video recordings demonstrated by a practicum assistant for the courses taken. One of the efforts that can be made to achieve the learning objectives of Organic Chemistry 2 is by giving assignments related to student practicums by taking a Science, Technology, Engineering and Mathematical (STEM) approach. STEM approach could help improve students' learning motivation and also had a positive effect on guiding students to complete STEM content [3].

Several problems that arise in the field and as an effort to support the Higher Education curriculum in the industrial era 4.0, high technology-based teaching materials are needed so that they can be used remotely/online. The current teaching materials are only reference books from the library or from Power Point (PPT) given by the course lecturers. Digital teaching materials using approaches, models and evaluations to measure student's higher-order thinking skills are still very limited. One approach or model that is an interesting issue to be developed is about STEM. In the Chemistry Education Study Program itself, learning with the STEM approach has never been done. STEM education presents problems related to the challenges of globalization and trains the skills needed for the 21 st century (21st century skills) and the innovations implied by the challenges of globalization [4]. STEM education is very suitable to be applied in learning in the 21 st century. STEM provides opportunities for students to apply the concepts of science, technology, engineering and mathematics, thus making learning more meaningful and challenging. The STEM approach is an option in developing digital teaching materials, especially in the Organic Chemistry 2 course. The teaching materials developed are using the Android-based STEM approach. The material that is the focus of the research is Lipid material. This material is part of the subject presented in the Organic Chemistry 2 course.

Based on the initial analysis carried out from the questionnaire made by the researcher to be filled in by the lecturer in organic chemistry courses, it is known that re-checking the Semester Lecture Plan (RPS) used by lecturers, books or teaching materials used, 
practicum guides and evaluation tools used. From the searches carried out, the RPS used by lecturers is still not in accordance with the Higher Education Curriculum in the Industrial Era 4.0 to support "Independent Campus, Freedom to Learn" (Kampus Merdeka, Merdeka Belajar) launched by the Minister of Education and Culture Nadiem Makarim in January 2020. The RPS created must be accompanied by other learning tools including: task plans, assessment instruments in the form of rubrics and/or portfolios, teaching materials, and others [5].

In STEM learning, cognitive abilities, personal motivation, conceptual knowledge, social skills, problem solving competencies, scientific discoveries, technological innovations and mathematical calculations can develop according to the demands of 21st century skills. The STEM approach is an approach that integrates Science, Technology, Engineering, and Mathematics, by focusing the educational process on solving real-life problems in daily life and professional life [6]. The STEM approach is able to integrate concepts, principles of science, technology, engineering and mathematics in the development of products, processes, and systems that provide benefits for human life. STEM in organic chemistry courses links several fields, namely science/ knowledge in the form of material presented in teaching materials. Science in this lipid material is in the form of a scientific process while tracing information about the structure, classification, source and function of lipid compounds. Various information was connected through books and journals on how to analyze/test lipid compounds, utilization of lipid compounds that are closely related to daily life. well as seeking the latest information related to research related to lipids. The technology used for this lipid material is in the form of searching for information through the internet in the form of books, videos, articles in journals related to lipid material. Use of Multiple ICTs in the process, such as Mendeley, Chemdraw, Chemsketch, Adobe Illustrator, Researchgate. net, Google Scholar, flip book pdf. Engineering in this lipid study, which trains students in engineering what components are used in information retrieval by making video assignments and project assignment reports. Mini-research design, in the form of efficient use of tools and materials to support the hypothesis made. Mathematical in learning lipids, namely in mathematical calculations on lipid analysis tests, method efficiency and utilization of lipids in everyday life. In lipid materials and applications.

The package of teaching materials that have been developed is presented in digital form, supporting higher education curriculum programs in the 4.0 era. The applications used in making digital books was Flip PDF Professional. This application is used because it is very practical, easy to make and can be uploaded online without having to install the application on a laptop or mobile phone.

In several previous studies that have succeeded in using this application, the response of students/students who use the flip book application is very positive, namely e-module that has been given makes it easier for the learning process, the material is clear and easy to understand, the practical video is also very helpful for students to learn independently both in class and outside the classroom [7]. The advantage of this Flip PDF Professional application is that it is easier to use because it does not require a programming language. The resulting e-book form is also very interesting and interactive because it can include multimedia such as images, videos from YouTube, MP4, audio videos, hyperlinks, quizzes, flash, and others [8]. 
Based on the above background, researchers are interested in developing an organic chemistry 2 lipid e-book using a STEM approach to improve students activity abilities and learning outcomes. This research is important because facing the 4.0 era, the need for digital teaching materials has become a necessity. Important components in teaching materials are also a concern as an effort to integrate several fields of Science, Technology, Engineering, and Mathematics with PjBL learning models that require students to think at a higher level, High Order Thinking Skills (HOTS).

\section{Method}

Based on the research objectives that have been set, this research is included in research and development (Research and Development). [9, 10, 11] stated that $\mathrm{R}$ and $\mathrm{D}$ tries to generate knowledge obtained from data that is systematically derived from what happened. The development procedure used in this study refers to the development model of Borg \& Gall [12], and is limited to the seventh stage including (1) research and information collecting, (2) planning, (3) developing preliminary form of product, (4) preliminary field testing, (5) main product revision, (6) main field testing, (7) operational product revision.

The subjects in this study were 9 students in semester VI with low abilities ( 3 students, 3 students with moderate abilities and 3 students with high abilities). The subjects used in this study were selected using the purposive sampling method. According to Sugiyono [13] Purposive Sampling is a sampling technique with certain considerations. The subject of this research was taken with the consideration that the students who are the sample are students where the researchers teach, and have facilities (supporting devices) to conduct online learning.

The data collected is in the form of inputs as outlined in the questionnaire and the results of the checklist of observation instruments which are recapitulated according to their components. The classified data is in the form of data grouping based on the observed/developed components including data related to product feasibility and student learning outcomes data, can be seen in Table 1.

Table 1. Data collection techniques

\begin{tabular}{|c|l|l|l|l|}
\hline No. & \multicolumn{1}{|c|}{ Data } & \multicolumn{1}{|c|}{ Source } & \multicolumn{1}{|c|}{$\begin{array}{c}\text { Data Collection } \\
\text { Technique }\end{array}$} & \multicolumn{1}{|c|}{ Data Analysis Method } \\
\hline 1. & $\begin{array}{l}\text { Eligibility of teaching } \\
\text { materials }\end{array}$ & Primary data & $\begin{array}{l}\text { Material and media } \\
\text { expert validation } \\
\text { questionnaire }\end{array}$ & $\begin{array}{l}\text { Descriptive quantitative, } \\
\text { qualitative }\end{array}$ \\
\hline 2. & Pretest results & Primary data & Test & Descriptive quantitative \\
\hline 3. & Posttest results & Primary data & Test & Descriptive quantitative \\
\hline 4. & $\begin{array}{l}\text { Readability test of teaching } \\
\text { materials }\end{array}$ & Primary data & Questionnaire & $\begin{array}{l}\text { Descriptive quantitative, } \\
\text { qualitative }\end{array}$ \\
\hline
\end{tabular}

The criteria used in determining the feasibility of teaching materials were analyzed descriptively by collecting quantitative and qualitative data. To measure the feasibility of the content of teaching materials is carried out by material experts (chemistry lecturers) 
while the feasibility of displaying teaching materials is carried out by media experts (learning technology lecturers and IT experts). The formula used in the descriptive analysis is calculated by the formula [14], namely:

$$
\mathrm{P}=\mathrm{f} / \mathrm{N} \times 100 \%
$$

Information:

$\mathrm{P}=$ Rating percentage

$\mathrm{f}=$ Score obtained

$\mathrm{N}=$ Overall score

The classification of data interpretation uses four scales based on the Likert scale, can be seen in Table 2 and percentage scale of validity assesment in Table 3 .

Table 2. E-book eligibility percentage interval

\begin{tabular}{|c|c|}
\hline Percentage Interval & Criteria \\
\hline $25 \%<\mathrm{P} 43.75 \%$ & Extremely not feasible \\
\hline $43.75 \%<\mathrm{P} 62.5 \%$ & Not feasible \\
\hline $62.5 \%<\mathrm{P} 81.25 \%$ & Feasible \\
\hline $81.25 \%<\mathrm{P} 100 \%$ & Extremely feasible \\
\hline
\end{tabular}

Table 3. Percentage scale of validity assessment [15]

\begin{tabular}{|c|c|}
\hline Achievement Score (score) & Validity Category \\
\hline $81.00 \%-100.00 \%$ & Very valid \\
\hline $61.00 \%-80.00 \%$ & Valid \\
\hline $41.00 \%-60.00 \%$ & Quite valid \\
\hline $21.00 \%-40.00 \%$ & Less valid \\
\hline $00.00 \%-21.00 \%$ & Very invalid \\
\hline
\end{tabular}

The readability test was conducted in small groups. The readability test data was obtained from the results of filling out the readability questionnaire by students. The score of the answer assessment results using a Likert scale which can be seen in Table 4.

Table 4. Answer choice assessment score [16]

\begin{tabular}{|c|c|}
\hline Category & Score \\
\hline SB (Very Good) & 5 \\
\hline B (Good) & 4 \\
\hline C (Enough) & 3 \\
\hline KB (Poor) & 2 \\
\hline SK (Very Poor) & 1 \\
\hline
\end{tabular}


The calculation of the percentage of the readability test uses the following formula:

$$
P=\frac{\sum R}{N} \times 100 \%
$$

Information:

$P=$ Percentage value readability test

$R=$ Total score

$N=$ Maximum score

The percentage of the readability test that has been obtained is converted to an assessment statement to determine the feasibility and quality of the resulting product in accordance with Table 5.

Table 5. Readability test criteria [17]

\begin{tabular}{|c|c|}
\hline Category & Percentage (\%) \\
\hline Very poor & $\mathrm{P}<20$ \\
\hline Poor & $21 \leq \mathrm{P}<40$ \\
\hline Pretty good & $41 \leq \mathrm{P}<60$ \\
\hline Good & $61 \leq \mathrm{P}<80$ \\
\hline Very good & $81 \leq \mathrm{P}<100$ \\
\hline
\end{tabular}

The average value of student learning outcomes, calculated by:

$$
\bar{x}=\frac{\sum x}{n}
$$

Information:

$\bar{x}$ : Mean

$x$ : Total data

$n$ : Amount of data [18]

Analysis of the effectiveness of the use of organic chemistry teaching materials 2 is seen from the results of the student understanding test. Product application testing was carried out on trials in small and large classes using the "one group pretest-posttest" design method with the experimental method [19]. According to Amrullah [20], to determine the effect of learning on Concept Mastery, an N-Gain Score analysis was carried out. Gain shows differences in student's conceptual mastery before and after being given treatment.

$$
N-\text { Gain }=\frac{\text { skor postest }- \text { skor pretest }}{\text { skor maksimum }- \text { skor pretest }}
$$

Information:

$N$-Gain : Normalized gain

pre test : The initial value of learning

Posttest: Final grade of learning 
To determine the level of student understanding after using the teaching materials developed for learning outcomes, the researcher used index criteria as a reference for assessing data. The criteria for the gain index can be seen in Table 6 .

Table 6. Gain index criteria [21]

\begin{tabular}{|c|c|}
\hline N-Gain & Category \\
\hline N-gain score 0.7 & High \\
\hline 0.3 N-gain score $<0.7$ & Medium \\
\hline N-gain score $<0.3$ & Low \\
\hline
\end{tabular}

\section{$3 \quad$ Result and discussion}

Organic chemistry teaching materials 2 using the STEM approach are designed to improve student learning outcomes. The development of these teaching materials is limited to only seven steps referring to the Borg and Gall development model. These stages include: Information collecting; planning; development of initial product format (develop preliminary form of product); validation test (preliminary field testing); initial product revision (main product revision); field testing (main field testing); product revision of field test results (operational product revision).

\subsection{Research and information gathering stage}

Interviews with lecturers. Interviews with lecturers were conducted to find out the learning activities that have been carried out so far, the lecturer's perceptions of the teaching materials used in learning, the implementation of learning that has been carried out so far and the problems that arise in learning. The results of the interview show that in the learning process, lecturers often use the discussion method by utilizing learning resources such as organic chemistry reference books, student discussion sheets, and the internet. The learning resources used can only help students understand some of the material. This is because the lecture material is quite dense in organic chemistry courses, especially organic chemistry 2 . The results of the interviews also show that the lecturers have never made and used teaching materials such as modules or e-books, lecturers still use power point and use several applications in learning such as e-learning, WhatsApp Group (WAG) and google classroom. In fact, the availability of facilities and infrastructure on campus is sufficient to support the implementation of digital-based learning by utilizing information and communication technology. The learning activities that have been carried out have not fully directed students to higher-order thinking skills. New lecturers make variations of sample questions with high-level thinking levels, but students still have difficulty learning to solve these problems.

The learning models and methods used are also still limited. Several cooperative learning models such as STAD, jigsaw, discussion, experiment and demonstration have been applied. Merging of several approaches or models that have not currently been 
carried out. Therefore, the researchers tried to apply the STEM approach in organic chemistry learning in order to increase student's motivation, creativity and higher-order thinking skills.

Analysis results of semester learning plan (RPS). At this stage, the researcher analyzes the RPS to map the Course Learning Outcomes (CPMK) related to the material taken by the researcher as the basis for making sub CPMK, indicators and learning objectives. The results of the RPS analysis used are still using the previous curriculum, not yet adjusted to the MBKM curriculum format. One of the important changes in this curriculum is learning that uses and adapts to the development of the industrial era 4.0 which uses a blended learning pattern. The current covid-19 pandemic requires learning in universities to be online (online).Online learning is a learning pattern using the internet in various types of distance learning interactions. In its implementation online learning requires the support of mobile devices such as Android phones or smartphones, laptops, computers, tablets, and iPhones that can be used to access information anywhere and anytime [22]. Online learning patterns are indeed needed in learning in the era of the industrial revolution 4.0 [23].

Active and innovative learning. The STEM approach is a learning approach that links the components of Science, Technology, Engineering and Mathematics in learning. These four components are actually interrelated with each other. Especially in Lipid material, this approach is very suitable to be applied because the 4 STEM components are related to each other. The STEM approach, which is collaborated with assignments to students, in the process can involve students in carrying out project/ experimental assignments so that students will be directly involved in scientific work that can train critical thinking skills, especially in formulating problems, formulating hypotheses, observing and considering observations, and draw a conclusion. The results of the subsequent analysis are used as the basis for developing organic chemistry learning materials.

\subsection{Planning stage}

At the planning stage, the researcher makes a product development design plan. The steps that taken by the researcher are to make a plan of teaching materials that will be made and developed. This teaching material consists of the front page, the title of the teaching material, an introduction consisting of an explanation of teaching materials in general, sub CPMK, indicators, objectives and benefits of learning. The learning material is divided into 2 chapters, namely about lipids in general and their applications.

Formulation of sub CPMK, indicators, objectives and benefits. The researcher formulates the learning sub-CPMK so that the desired learning achievement is known, both in measuring student's cognitive, attitudes and skills. Indicators, objectives and benefits of learning need to be formulated to be known by students as the results they achieve after using teaching materials. Sub CPMK in organic chemistry 2 course is after following this course students are expected to be able to classify types of lipids, their properties, reactions, sources and explain methods of lipid analysis. The learning objectives achieved after the implementation of learning using this material, namely 
in terms of cognitive, psychomotor, and affective aspects. The final goal achieved in the cognitive aspect is that students can demonstrate mastery of Lipids, students can demonstrate mastery in conducting STEM-based lipid projects. In the psychomotor aspect, students can understand the working principle and carry out lipid application project tasks using the STEM approach. In the affective aspect, students can make progress in showing the character of honesty, creative, independent, democratic, curious, communicative. Students can make progress in demonstrating behavioral social skills asking questions, contributing ideas/opinions, being a good listener and communicative. The benefit of this teaching material is that it is expected to help students understand about lipid material, lipid classification, structure, writing method, nomenclature, properties, reactions, sources and use of lipid compounds. Students are expected to play an active role and interact with the teaching materials provided.

Preparation of teaching materials. The preparations used in organic chemistry teaching materials 2 include the selection of theories, examples or illustrations, supporting images, supporting animations, and video supporting materials. The selected material is lipid material in the form of understanding, classification, source, function, analysis and use of lipids in daily life, practice questions and ability tests 1 . The next chapter is STEM learning on Lipid application. In this chapter the learning activities are divided into 3 learning units, namely materials for making VCO, purifying used palm oil andthe manufacture of red palm oil and the material on how to analyze the resulting oil. Followed by an independent task in the form of a lipid application project according to the STEM syntax accompanied by evaluation questions in the form of pretest and posttest.Materials were obtained from various sources, including reference books, journals, and other sources. Animated videos prepared in teaching materials for some materials about lipids and videos for making VCO, purificationused palm oiland manufacture of palm red oil.

Planning evaluation tools used. To see the impact of developing teaching materials using this STEM approach, it is necessary to prepare tests in the form of pretest and posttest after implementation. The tests given will be prepared directly from digital teaching materials developed using Google Forms.

Android-based teaching materials are made in 3 file versions, namely:

\section{Portable Document Format (PDF)}

This version is made so that books can be printed (print out), safe against virus attacks, can be uploaded and accessed easily and can be opened offline. The weakness of the pdf version cannot be displayed video, audio and animation in the e-book.

\section{Pdf Flip Book Maker}

This version is made so that the PDF display becomes attractive like a book and can be equipped with videos and animations. This book can display a series of images that vary from page to page, as the pages flip through quickly. The image appears to be animated by the stimulated motion, making it more interesting. This version is also made to facilitate the dissemination stage (disseminate). The flip book version is equipped with navigation buttons to make it easier to use e-books like digital books in general, namely: 
1) Zoom in: to enlarge and reduce the appearance of the e-book if needed, to make it easier to read the e-book.

2) Thumbnails: a type of small image file to speed up the work (loading) of android, computers or laptops when reading and displaying/previewing small image files.

3) Stop Auto Flip.

4) Sound offlon.

5) Backward, first, previous, next, last, forward: to make it easier to open the pages and switch pages in the e-book when in use. Readers can also directly go to the desired page by typing the number of the destination page on the navigation button.

6) Share: easy sharing using QRCode on android.

7) Share by Email.

8) Exit and Esc Full Screen.

\subsection{Product draft development stage}

The next stage is product development. The teaching materials that the researchers developed are Android-based e-books using the Pdf Flip Professional application which previously were made in .docx format and then converted into .pdf format. Teaching materials are converted to applications and published online in the form of links. After e-books are published online and offline, students can access e-books via laptop and smartphones. The display of the e-book can be seen in Figure 1.

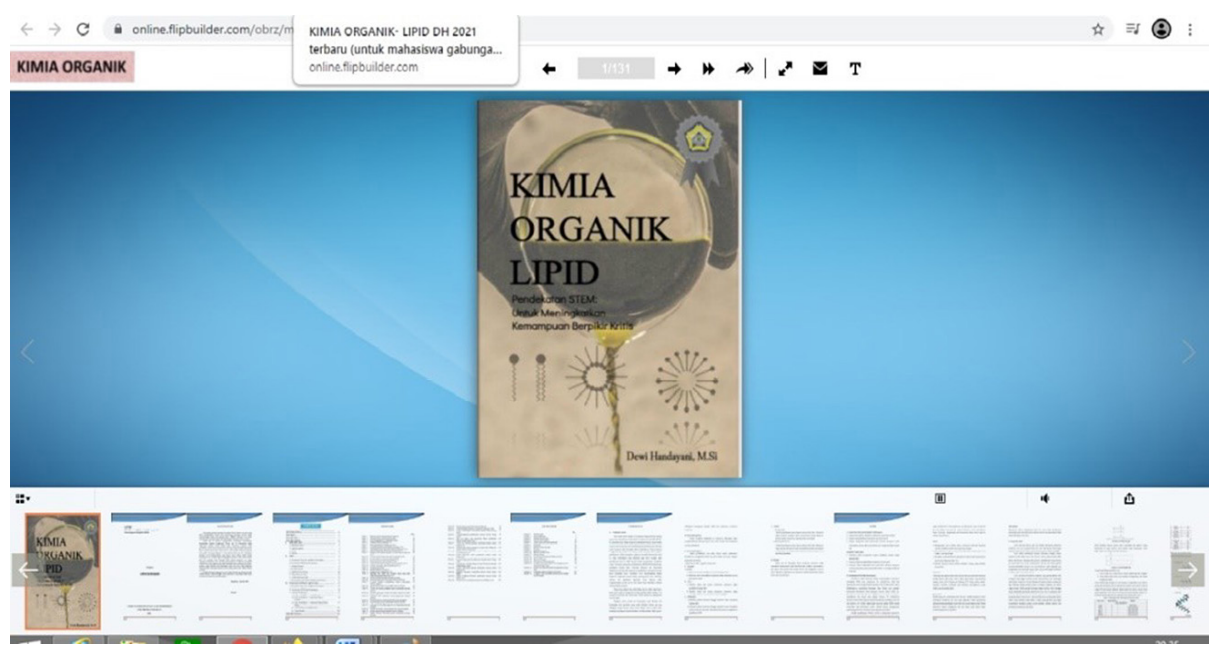

Fig. 1. Display of the e-book on the development draft

Furthermore, the parts of the teaching materials that the researchers developed are as follows: 
a. Front cover

The front cover consists of the title of teaching materials, pictures, names and logos of the constituent institutions. The cover page of the e-book is packaged with various images, colors and the layout of the cover of teaching materials is also adjusted in such a way that it looks attractive to students in studying this e-book.

\section{b. Beginning part}

The initial part of the e-book consists of an introduction, table of contents, list of tables, list of pictures, list of attachments, introduction consisting of a general explanation of lipid material using the STEM approach, sub CPMK, objectives and benefits of learning.

c. Contents section

The content section of the e-book consists of a description of the material in learning activity 1 and learning activity 2, namely on lipid material and STEM learning on lipid applications. Each learning activity includes a Science, Technology, Engineering and Mathematical (STEM) approach.

\section{1) Science:}

At this stage using the scientific process while tracing information about the structure, classification, source and function of lipid compounds. Connect various information through books, journals about how to analyze/test lipid compounds. Explain the material of lipids and the use of lipid compounds that are closely related to everyday life. Looking for the latest information on research related to lipids.

\section{2) Technology:}

At this stage, the technology used for this lipid material is in the form of searching for information via the internet, either books, videos, articles in journals related to lipid material. Use of Multiple ICTs in the process, such as Mendeley, Chemdraw, Chemsketch, Adobe Illustrator, Researchgate.net, Google Scholar, as well as lipid analysis tools.

\section{3) Engineering:}

At the engineering stage in this lipid learning, which is to train students in engineering what components are used in information retrieval by making video assignments and project assignment reports. Mini-Research Design, in the form of efficient use of tools and materials to support the hypothesis made.

\section{4) Math:}

At this mathematical stage in lipid learning, namely in mathematical calculations on lipid analysis tests, method efficiency and lipid utilization in everyday life.

\section{d. Final part}

The final part of the e-book consists of self-assessment, comprehension test, and bibliography. 


\subsection{Initial field trial stage}

The validation test was conducted to ask for expert consideration, material experts and media experts on the products developed by researchers. Material experts and media experts who are experienced in their fields. This step is carried out to determine the level of product feasibility using a questionnaire, so that researchers know the strengths and weaknesses of the developed e-book, which is then used as material for revising the e-book.

Material expert validation results. The validation of this material was carried out by 3 material experts, Professors and Doctors of Chemistry from the University of Bengkulu and Education and Training Center for IPA Kemendikbud. Validation of this material is carried out to determine the feasibility of teaching materials based on several aspects/indicators including: the feasibility aspect of presenting the material, the content feasibility aspect, the language feasibility aspect and the STEM aspect. This aspect was developed from the aspect of the instrument issued by the National Education Standards Agency (BSNP). The questionnaire for material expert validators has 14 assessment indicators spread over 25 questions. In addition to providing an assessment using a Likert scale (1-4), the validator provides comments or suggestions on teaching materials developed in accordance with the STEM approach to improve the teaching materials produced. The results of the assessment are obtained through the validation sheet of each validator and are presented in the form of Table 7 below:

Table 7. Material expert validation results

\begin{tabular}{|c|c|c|c|c|c|}
\hline \multirow{2}{*}{ No. } & \multirow{2}{*}{ Aspect Question } & \multicolumn{3}{|c|}{ Validator } & \multirow{2}{*}{ Average } \\
\hline & & 1 & 2 & 3 & \\
\hline 1. & $\begin{array}{l}\text { Aspects of Feasibility of Presentation } \\
\text { of Materials ( } 8 \text { questions) }\end{array}$ & 29 & 29 & 29 & 29 \\
\hline 2. & $\begin{array}{l}\text { Content Feasibility Aspect } \\
\text { (10 questions) }\end{array}$ & 37 & 36 & 39 & 37.33 \\
\hline 3. & $\begin{array}{l}\text { Language Eligibility Aspect } \\
\text { (4 questions) }\end{array}$ & 15 & 14 & 16 & 15 \\
\hline \multirow[t]{6}{*}{4.} & STEM Aspects (3 questions) & 12 & 12 & 12 & 12 \\
\hline & Overall score & 93 & 91 & 96 & 93.33 \\
\hline & Number of items & 25 & 25 & 25 & 25 \\
\hline & Rating percentage $(\%)$ & 93 & 91 & 96 & 93.33 \\
\hline & Eligibility category & $\begin{array}{c}\text { Very } \\
\text { Feasible }\end{array}$ & $\begin{array}{c}\text { Very } \\
\text { Feasible }\end{array}$ & $\begin{array}{c}\text { Very } \\
\text { Feasible }\end{array}$ & $\begin{array}{c}\text { Very } \\
\text { Feasible }\end{array}$ \\
\hline & Validity category & Very valid & Very valid & Very valid & Very valid \\
\hline
\end{tabular}

The percentage of each aspect of the material expert validator team is presented in Table 8 . 
Table 8. Results of material expert validation on each aspect

\begin{tabular}{|c|l|c|c|c|}
\hline \multirow{2}{*}{ No. } & \multicolumn{2}{|c|}{ Assessment Aspect } & \multicolumn{3}{c|}{ Validator } \\
\cline { 3 - 5 } & & $\mathbf{1}$ & $\mathbf{2}$ & $\mathbf{3}$ \\
\hline 1. & Feasibility Aspects of Material Presentation & $90.63 \%$ & $90.63 \%$ & $90.63 \%$ \\
\hline 2. & Content Feasibility Aspect & $92.5 \%$ & $90 \%$ & $97.5 \%$ \\
\hline 3. & Language Eligibility Aspect & $93.75 \%$ & $87.5 \%$ & $100 \%$ \\
\hline 4. & STEM aspects & $100 \%$ & $100 \%$ & $100 \%$ \\
\hline
\end{tabular}

Based on the results of the feasibility test analysis by a number of experts, organic lipid chemistry teaching materials are included in the category of teaching materials that are very feasible to use with an average of 93.33 or the validity criteria are very valid. These results indicate that teaching materials can be used for the next stage.

On the aspect feasibility of presenting material, aspects of content feasibility, aspects of language feasibility three material experts gave a very decent score with few revisions. On the STEM aspect of the category is very feasible and without any revision. Recommendations for improvement from experts are used as a reference for improving and perfecting the developed lipid organic chemistry teaching materials.

Validation results by media experts. The media expert validation was carried out by two professors of Educational Science Technology, 1 computer expert/educational technology expert lecturer and 1 linguist expert lecturer. This media validation is carried out to see the feasibility of the technical quality aspects of the media, program display aspects and language feasibility aspects in the developed media. The questionnaire sheet consists of 13 assessment questions and is equipped with comments or suggestions so that it can be used as a revision of the resulting product improvements. Based on the validation sheet that has been filled out by each validator, the results of the feasibility assessment of the practicum guide are obtained which are presented in Table 9 below:

Table 9. Media expert validation results

\begin{tabular}{|c|c|c|c|c|c|c|}
\hline \multirow{2}{*}{ No. } & \multirow{2}{*}{ Aspect Question } & \multicolumn{4}{|c|}{ Validator } & \multirow{2}{*}{ Average } \\
\hline & & 1 & 2 & 3 & 4 & \\
\hline 1. & $\begin{array}{l}\text { Technical Quality } \\
\text { Aspect (2 questions) }\end{array}$ & 8 & 8 & 8 & 8 & 8 \\
\hline 2. & $\begin{array}{l}\text { Aspects of Program } \\
\text { Display ( } 8 \text { questions) }\end{array}$ & 29 & 32 & 30 & 30 & 30.25 \\
\hline \multirow[t]{5}{*}{3.} & $\begin{array}{l}\text { Language Eligibility } \\
\text { Aspects (3 questions) }\end{array}$ & 12 & 12 & 12 & 10 & 11.5 \\
\hline & Overall score & 49 & 52 & 50 & 48 & 49.75 \\
\hline & Number of items & 13 & 13 & 13 & 13 & 13 \\
\hline & $\%$ Validity & 94.23 & 100 & 96.15 & 92.31 & 95.67 \\
\hline & Category & Very valid & Very valid & Very valid & Very valid & Very valid \\
\hline
\end{tabular}


The percentage of each aspect of the media expert validator is presented in Table 10:

Table 10. Percentage of media expert validation results

\begin{tabular}{|c|l|c|c|c|c|}
\hline \multirow{2}{*}{ No. } & \multirow{2}{*}{ Assessment Aspect } & \multicolumn{4}{|c|}{ Validator } \\
\cline { 3 - 6 } & & $\mathbf{1}$ & $\mathbf{2}$ & $\mathbf{3}$ & $\mathbf{4}$ \\
\hline 1. & Technical Quality Aspect & $100 \%$ & $100 \%$ & $100 \%$ & $100 \%$ \\
\hline 2. & Program Display Aspect & $90.63 \%$ & $100 \%$ & $93.75 \%$ & $93.75 \%$ \\
\hline 3. & Language Eligibility Aspect & $100 \%$ & $100 \%$ & $100 \%$ & $83.33 \%$ \\
\hline
\end{tabular}

The validation results show that in terms of technical quality, in terms of the effectiveness of using media, practicality and simplicity in operation, there is no revision and is considered very feasible by the validator. In the aspect of the display/design of the developed media, there are still some things that need to be revised, especially on the front cover, the cover of teaching materials on color selection and image design needs to be reviewed. The results of this media validation are in accordance with previous research where the overall quality of the media assessed by media experts is $85 \%$ with the very good category [24].

\subsection{Revision of trial results}

The initial product revision was carried out based on the results of the validation test in the form of assessments, comments and suggestions from material experts and media experts. The results of the validator's assessment on the questionnaire concluded that the e-book was declared very feasible for field trials with minor revisions.

\subsection{Field trials}

Field trial was conducted to determine the readability of the teaching materials developed and the level of student understanding of the e-book that the researcher developed with a limited number of students (small group trial). Field trials were carried out on students of Bengkulu University Chemistry Education who had taken organic chemistry 2 courses, totaling 9 students based on the level of student ability, 3 students with high abilities, 3 students with moderate abilities, and 3 students with low abilities. Students are asked to fill out a readability questionnaire for the e-book that was developed. The data from the e-book readability test results can be seen in Table 11. 
Table 11. Results of e-book readability trials in small classes

\begin{tabular}{|c|l|c|c|}
\hline No. & \multicolumn{1}{|c|}{ Aspect Question } & Percentage (\%) & Category \\
\hline 1. & Sentence effectiveness. & 93.33 & Very good \\
\hline 2. & Communicative sentence. & 91.11 & Very good \\
\hline 3. & Sentences do not have a double meaning. & 86.67 & Very good \\
\hline 4. & $\begin{array}{l}\text { The language used is in accordance with the } \\
\text { level of student development. }\end{array}$ & 86.67 & Very good \\
\hline 5. & Use of typeface. & 97.78 & Very good \\
\hline 6. & Use of font size. & 93.33 & Very good \\
\hline 7. & Use of spacing. & 97.78 & Very good \\
\hline & Average & 92.38 & Very good \\
\hline
\end{tabular}

Students are also asked to fill out the tests that contained in the e-book. Student learning outcomes in small classes can be seen in Table 12.

Table 12. Student learning outcomes in small class

\begin{tabular}{|c|c|c|c|}
\hline Student Code Name & Ability & Pretest Score & Posttest Score \\
\hline PNS & High & 70 & 92.5 \\
\hline DRS & High & 72.5 & 92.5 \\
\hline YA & High & 60 & 92.5 \\
\hline DNS & Medium & 50 & 82.5 \\
\hline SPS & Medium & 52.5 & 82.5 \\
\hline RY & Medium & 62.5 & 82.5 \\
\hline RSL & Low & 42.5 & 62.5 \\
\hline RJI & Low & 50 & 60 \\
\hline PKR & Low & 40 & 60 \\
\hline Total & & 500 & 707.5 \\
\hline Average & & 55.56 & 78.61 \\
\hline & N-gain & 0.52 & \\
\hline & Category & Medium & \\
\hline
\end{tabular}

Based on Table 12, the posttest scores obtained are $\geq 60$, which means that students are able to answer the evaluation tests presented in the e-book. With the Pass criteria if categorized in the passing grade at Bengkulu University (Score 56, Letter C, pass category). The average value of the pretest is 55.56, the post-test value is 78.61. An increase of 23.05. With an N-gain of 0.52 (including the medium category).

The results of the normality test of learning outcomes data can be seen in Table 13 . 
Table 13. Normality test of small class learning outcomes

\begin{tabular}{|l|l|c|}
\hline \multicolumn{2}{|c|}{ One-Sample Kolmogorov-Smirnov Test } \\
\hline \multirow{2}{|c|}{$\mathrm{N}$} & Unstandardized Residual \\
\hline \multirow{2}{*}{ Normal Parameters } & Mean & 9 \\
\cline { 2 - 3 } & Std. Deviation & .0000000 \\
\hline \multirow{4}{*}{ Most Extreme Differences } & Absolute & 7.33560480 \\
\cline { 2 - 3 } & Positive & .248 \\
\cline { 2 - 3 } & Negative & .248 \\
\hline Kolmogorov-Smirnov Z & -.200 \\
\hline Asymp. Sig. (2-tailed) & .744 \\
\hline a. Test distribution is Normal. & .637 \\
\hline
\end{tabular}

If the significance value $>0.05$, then the data is normally distributed. Based on the results of normality, the value of sig (2-tailed) was 0.637 . This means that the value $>0.05$. it can be concluded that the residual value is normally distributed. The results of the $t$ test can be seen in Table 14.

Table 14. T test of learning outcomes paired samples test

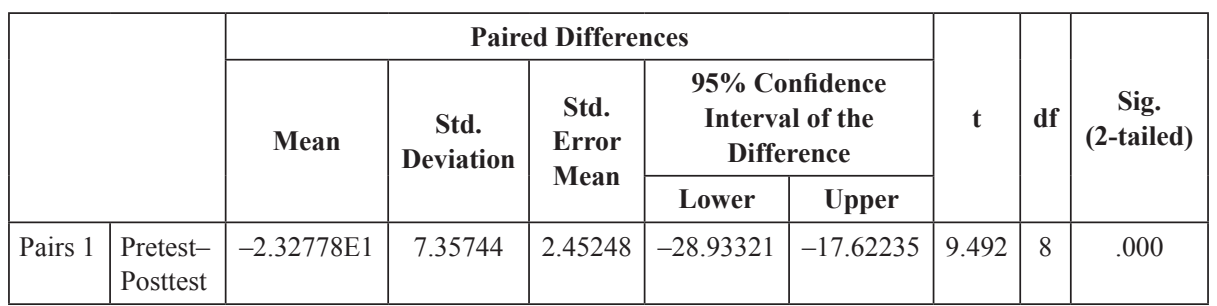

Based on Table 14 Significant value (2-tailed) $<0.00$. Less than 0.05 indicates a significant difference between the initial and final variables. This means that there is a significant effect on the treatment given.

\subsection{Product revision}

Based on the results of field trials through readability questionnaires and e-book learning outcomes in small classes in Table 11 and Table 12 show that the average e-book readability questionnaire is $92.38 \%$ with a very good category and the average student learning outcomes in small class of $78.61 \%$ in the Good category. From the results obtained it can be concluded that The e-book that the researcher developed does not need to be revised and is ready to be tested.

STEM-based organic chemistry learning is carried out with an effort to develop student abilities suitable for 21 st century learning. The implementation of STEM in organic chemistry 2 lectures is shown in Table 15 below. 
Table 15. Integration of STEM in lipid organic chemistry, examples of producing VCO

\begin{tabular}{|l|l|l|l|}
\hline \multicolumn{1}{|c|}{ Science } & \multicolumn{1}{|c|}{ Technology } & \multicolumn{1}{c|}{ Engineering } & \multicolumn{1}{c|}{ Mathematic } \\
\hline $\begin{array}{l}\text { Lipid Application } \\
\text { Concept in VCO }\end{array}$ & $\begin{array}{l}\text { Heating, enzymatic and stirring } \\
\text { technology }\end{array}$ & $\begin{array}{l}\text { Design a simple tool } \\
\text { for making VCO }\end{array}$ & $\begin{array}{l}\text { Calculation of } \\
\text { tools and materials } \\
\text { needed }\end{array}$ \\
\hline $\begin{array}{l}\text { Testing the physical } \\
\text { properties of the } \\
\text { resulting oil }\end{array}$ & $\begin{array}{l}\text { Utilization of technology to find } \\
\text { references/supporting literature via } \\
\text { the internet, mobile phones and } \\
\text { other supporting technologies. } \\
\text { Utilization of youtube social media } \\
\text { to share information about some } \\
\text { lipid applications in daily life }\end{array}$ & $\begin{array}{l}\text { Make a design } \\
\text { for testing tools/ } \\
\text { properties of the oil } \\
\text { obtained }\end{array}$ & $\begin{array}{l}\text { Measurement and } \\
\text { calculation of the } \\
\text { physical properties } \\
\text { of the obtained oil }\end{array}$ \\
\hline
\end{tabular}

STEM-based teaching materials developed by researchers in the form of e-books made with android-based. The development of these teaching materials is carried out through a series of stages as stated in the previous chapter. Furthermore, in order to improve the process of preparing teaching materials before experimental research is carried out, a limited field test is carried out. This activity is in line with the demands and obligations of lecturers in the UU on Lecturers and Lecturers no. 14 of 2005 [25], to be able to compile innovative teaching materials in accordance with the curriculum, the development of student needs and the development of information technology.

The results of the development of Android-based organic chemistry 2 teaching materials that are developed can have advantages, including: (1) This teaching material can be opened anywhere and anytime because it is based on an android application, so it can support student learning. This is in line with previous research which states that electronic media can be opened anywhere and without time restrictions [26]. (2) The application that made has a small capacity and can be downloaded by all types of Android while having internet connection and memory on the smartphone. The small capacity of this application will not interfere with its operation on a smartphone. (3) The material presented in this teaching material uses a STEM (Science, Technology, Engineering, Mathematical) approach that can support good learning in the fields of science, technology and mathematics.

\section{Conclusion}

From the results and discussion, it can be concluded that android-based teaching materials which was developed was considered feasible by the material expert validator with a percentage score of $93.33 \%$ (very feasible category). Media experts with an average of $95.67 \%$ with a very feasible. Field trial This study was conducted to determine the readability of the developed teaching materials and student learning outcomes of the developed teaching materials. The results of the readability test of teaching materials obtained an average of 92.38 with a very good category and the average student learning outcomes in small classes is $78.61 \%$ in the Good category, with the average student learning outcomes pretest and posttest scores. It is recommended for further research by testing the teaching materials developed into a wider field test. The STEM approach can be integrated with learning models that can improve student learning outcomes. 


\section{$5 \quad$ References}

[1] Huseno, T. (2018). Strategi Perguruan Tinggi dalam Upaya Meningkatkan Kualitas Sumberdaya Manusia Menghadapi Era Revolusi Industri 4.0. REKAMAN.

[2] Handayani, D., \& Alperi, M. (2021). Problem solving learning model using video application. In Journal of Physics: Conference Series (Vol. 1731). IOP Publishing Ltd. https://doi. org/10.1088/1742-6596/1731/1/012024

[3] Zhuang, Y., Wang, L., \& Chiang, F. (2018). The Design and Development of a Mobile Phone Application for STEM based on a Novel Engineering Approach. International Journal of Advanced Corporate Learning (IJAC), 11(2), 16. https://doi.org/10.3991/ijac.v11i2.9233

[4] Bybee, R. W. (2013). The case for STEM education: Challenges and opportunity. Arlington, VI: National Science Teachers Association (NSTA) Press.

[5] Junaidi, A., dkk. (2020). Panduan Penyusunan Kurikulum Pendidikan Tinggi Di Era Industri 4.0 Untuk Mendukung Merdeka Belajar-Kampus Merdeka, Jakarta: Direktorat Pembelajaran dan Kemahasiswaan, Direktorat Jenderal Pendidikan Tinggi, Kementerian Pendidikan dan Kebudayaan.

[6] National STEM Education Centre. (2014). STEM education network manual. Bangkok: The Institute for the Promotion of Teaching Science and Technology.

[7] Romayanti, C., Sundaryono, A., \& Handayani, D. (2020). Pengembangan E-modul kimia Berbasis Kemampuan Berpikir Kreatif dengan menggunakan Kvisoft Flipbook Maker. Alotrop, 4(1). https://doi.org/10.33369/atp.v4i1.13709

[8] Professional, F. P. D. F., Flip, W., Professional, P. D. F., Windows, F., Service, O., \& Upgrade, P. (2019). Flip PDF Professional Interactive publishing — add video, image, link and. [Online]. Available: https://www.pdf-flip.com

[9] Richey, R. C., Klein, J. D., \& Nelson, W. A. (2004). Developmental Research: Studies of Instructional Design and Development. In D. H. Jonassen (Ed.), Handbook of research on educational communications and technology (pp. 1099-1130). Lawrence Erlbaum Associates Publishers.

[10] Seel, B. B. \& Richey, R. C. (1994). Instructional Technology: The Definition and Domains of the Field. Washington, DC: AECT.

[11] Van Den Akker, J. (1999). Principles and methods of development research. In: Van Den Akker, J., Nieveen, N., Branch, R. M., Gustafson, K. L., \& Plomp, T., Eds., Design Methodology and Developmental Research in Education and Training, Kluwer Academic Publishers, The Netherlands, 1-14. https://doi.org/10.1007/978-94-011-4255-7_1

[12] Borg, W. R., \& Gall, M. D. (1983). Educational research: An introduction. London: Longman, Inc.

[13] Sugiyono. (2012). Metode Penelitian Kuantitatif Kualitatif dan R\&D. Bandung: Alfabeta. ISBN: 9798433718.

[14] Anas Sudijono. (2008). Pengantar Statistik Pendidikan. Jakarta: Raja Grafindo Persada.

[15] Akbar, S. (2013). Instrumen Perangkat Pembelajaran. Bandung: PT Remaja Rosdakarya.

[16] Sugiyono (2015). Metode Penelitian Kombinasi (Mix Methods). Bandung: Alfabeta.

[17] Akbar, S. (2016). Instrumen Perangkat Pembelajaran. Bandung: PT Remaja Rosdakarya Offset.

[18] Riduwan. (2005). Skala Pengukuran Variabel Penelitian. Bandung: Alfabeta.

[19] Arikunto, S. (2012). Prosedur Penelitian Suatu Pendekatan Praktis. Edisi Revisi VI. Jakarta: PT. Rineka Cipta.

[20] Amrullah, A. K., Ibrahim, M., \& Widodo, W. (2017). Implementasi Pembelajaran Berbasis Masalah untuk Melatihkan Kemampuan Berpikir Kreatif dan Penguasaan Konsep Siswa Kelas V Sekolah Dasar. Jurnal Review Pendidikan Dasar: Jurnal Kajian Pendidikan dan Hasil Penelitian, 3(1), 378-387. https://doi.org/10.26740/jrpd.v3n1.p378-387 
[21] Rachmawati, D., Suhery, T., \& Anom, K. (2017). Pengembangan Modul Kimia Dasar Berbasis STEM Problem Based Learning pada Materi Laju Reaksi Untuk Mahasiswa Program Studi Pendidikan Kimia. Prosiding Seminar Nasional Pendidikan IPA 2017, 239-248.

[22] Gikas, J., \& Grant, M. M. (2013). Mobile computing devices in higher education: Student perspectives on learning with cellphones, smartphones \& social media. Internet and Higher Education. https://doi.org/10.1016/j.iheduc.2013.06.002

[23] Pangondian, R. A., Santosa, P. I., \& Nugroho, E. (2019). Faktor-Faktor Yang Mempengaruhi Kesuksesan Pembelajaran Daring Dalam Revolusi Industri 4.0. In Seminar Nasional Teknologi Komputer \& Sains (SAINTEKS) 1(1).

[24] Sarita, A. (2020). Pengembangan KIT Praktikum Skala Kecil Pada Materi Asam Basa di Mas Darul Hikmah Kajhu Aceh Besar. Banda Aceh: Fakultas Tarbiyah dan Keguruan.

[25] UU Dosen dan Dosen No. 14 tahun 2005.

[26] Handayani, D., Elvinawati, E., Isnaeni, I., \& Alperi, M. (2021). Development of guided discovery based electronic module for chemical lessons in redox reaction materials. International Journal of Interactive Mobile Technologies (IJIM), 15(07), 94. https://doi.org/ $\underline{10.3991 / \mathrm{ijim} . v 15 \mathrm{i} 07.21559}$

\section{Authors}

Dewi Handayani is a lecturer in the Education Chemistry Study Program at the Department of Science Mayor Education at Universitas Bengkulu, Indonesia. Email: d.handayani@unib.ac.id, ID Scopus: 57222159741, https://www.scopus.com/authid/ detail.uri?authorId=57222159741. ID Orchid: $\underline{0000-0003-1113-1543 .}$.

Endang Widi Winarni is a lecturer and proffesor in the Department of Elementary Education, Education Faculty, Universitas Bengkulu, Indonesia. Email: endangwidi@, unib.ac.id, ID Scopus: 57201680481, https://www.scopus.com/authid/detail.uri?authorId=57201680481. ID Orchid: 0000-0002-9761-4716.

Agus Sundaryono is a lecturer in the Graduate School of Science Education, Bengkulu, Indonesia. Email: asundaryono@unib.ac.id, ID Scopus: 6507690322, https://www.scopus.com/authid/detail.uri?authorId=6507690322.

M. Lutfi Firdaus is a lecturer and proffesor in the Graduate School of Science Education, Bengkulu, Indonesia. Email: lutfi@unib.ac.id, ID Scopus: 57220603047, https://www.scopus.com/authid/detail.uri?authorId=57220603047. ID Orchid: 00000002-5627-5834.

Muzanip Alperi, is an educational technology developer at Indonesia. Email: muzanip079@gmail.com. ID Scopus: 57222097774, https://www.scopus.com/authid/detail. uri?authorId=57222097774. ID orchid: 0000-0002-9344-7519.

Article submitted 2021-12-12. Resubmitted 2022-01-05. Final acceptance 2022-01-09. Final version published as submitted by the authors. 